ARTICLE

Received 9 Sep 2013 | Accepted 12 Nov 2013 | Published 17 Dec 2013

DOl: $10.1038 /$ ncomms3921

\title{
The discovery of kimberlites in Antarctica extends the vast Gondwanan Cretaceous province
}

\author{
Gregory M. Yaxley', Vadim S. Kamenetsky ${ }^{2,3}$, Geoffrey T. Nichols ${ }^{4}$, Roland Maas ${ }^{5}$, \\ Elena Belousova ${ }^{4}$, Anja Rosenthal ${ }^{1,6} \&$ Marc Norman ${ }^{1}$
}

Kimberlites are a volumetrically minor component of the Earth's volcanic record, but are very important as the major commercial source of diamonds and as the deepest samples of the Earth's mantle. They were predominantly emplaced from $\approx 2,100 \mathrm{Ma}$ to $\approx 10 \mathrm{ka}$ ago, into ancient, stable regions of continental crust (cratons), but are also known from continental rifts and mobile belts. Kimberlites have been reported from almost all major cratons on all continents except for Antarctica. Here we report the first bona fide Antarctic kimberlite occurrence, from the northern Prince Charles Mountains, emplaced during the reactivation of the Lambert Graben associated with rifting of India from Australia-Antarctica. The samples are texturally, mineralogically and geochemically typical of Group I kimberlites from more classical localities. Their $\approx 120 \mathrm{Ma}$ ages overlap with those of many kimberlites from other world-wide localities, extending a vast Cretaceous, Gondwanan kimberlite province, for the first time, into Antarctica.

\footnotetext{
${ }^{1}$ Research School of Earth Sciences, The Australian National University, Australian Capital Teritory 0200, Australia. ${ }^{2}$ ARC Centre of Excellence in Ore Deposits, University of Tasmania, Tasmania 7001, Australia. ${ }^{3}$ Institute for Marine and Antarctic Studies, University of Tasmania, Tasmania 7001, Australia. ${ }^{4}$ GEMOC, Department of Earth \& Planetary Sciences, Macquarie University, New South Wales 2109, Australia. ${ }^{5}$ School of Earth Sciences, University of Melbourne, Victoria 3010, Australia. ${ }^{6}$ Bayerisches Geoinstitut, University of Bayreuth, 95440 Bayreuth, Germany. Correspondence and requests for materials should be addressed to G.M.Y. (email: greg.yaxley@anu.edu.au).
} 
K imberlites are rare, highly silica-undersaturated, mantlederived igneous rocks, which have been emplaced into the crust, particularly in ancient and geologically stable cratons. Their trace element enrichments, small volumes, low silica but highly magnesian and volatile $(\mathrm{C}-\mathrm{H}-\mathrm{O})$-rich character argue that they represent melt compositions formed in the presence of $\mathrm{H}_{2} \mathrm{O}$ and $\mathrm{CO}_{2}$, very close to the carbonate-peridotite solidus $^{1-3}$. The occasional but scientifically and commercially highly significant presence of diamonds suggests that they originated by partial melting of the mantle at extreme depths $(>150 \mathrm{~km}$ ), and some kimberlites (that is, those transporting diamonds with inclusions representing rare transition zone and lower mantle mineral phases) are the most deeply derived materials accessible on Earth. Kimberlites were emplaced over a significant period of geological history, ranging in age from the Palaeoproterozoic to the Cenozoic Eras, and have been reported on all continents except Antarctica ${ }^{4,5}$.

Here we present mineralogical and geochemical data from three new kimberlite samples obtained from the southeastern slopes of Mt Meredith in the northern Prince Charles Mountains (nPCM) of Antarctica. These rocks represent the first reported occurrence of genuine kimberlite in Antarctica.

\section{Results}

Sample locations and petrography and mineralogy. The location from which the samples were recovered is shown in Fig. 1. One sample (77063) was obtained in situ from an outcrop, and the others (77081 and 77082) were recovered from boulders in till several metres from the outcrop. The three samples are classified as Group I kimberlites on the basis of petrography and mineral chemistry. They are strongly porphyritic with rounded to euhedral olivine crystals up to several millimetres across and rare phlogopite macrocrysts in a very fine-grained groundmass. Olivine crystals are partially replaced by serpentine on rims and along fractures (Fig. 2a, b), but all samples retain abundant fresh olivine. Most olivine crystals are rounded to euhedral in shape and up to $200 \mu \mathrm{m}$ across. Others are larger ( $>1 \mathrm{~mm}$ across) and irregular in shape, and sometimes contain inclusions of phlogopite, orthopyroxene, $\mathrm{Cr}$-diopside-rich clinopyroxene, perovskite and $\mathrm{Cr}$-spinel (Fig. 2c). Olivine crystals vary significantly in major and minor element compositions (from $\mathrm{Fo}_{74}$ to $\mathrm{Fo}_{91} ; 0.02-0.45$ wt $\% \mathrm{NiO}$ and $0.10-0.50 \mathrm{wt} \% \mathrm{CaO})$. In some cases, they are interpreted as xenocrysts of lithospheric material rather than as phenocrysts. For example, one large olivine crystal has an embayed and resorbed core of $\mathrm{Fo}_{90.5}$ olivine overgrown by a thin rim of $\mathrm{Fo}_{88}$ olivine. The core contains separate inclusions of $\mathrm{Cr}$ - and $\mathrm{Na}$-rich clinopyroxene as well as low $\mathrm{Al}$ and $\mathrm{Ca}$ orthopyroxene, which are compositionally similar to peridotitic phases from the upper mantle. Phlogopite macrocrysts can be up to several millimetres in length and are irregular to tabular in shape. Phlogopite $\mathrm{Mg}^{\#}\left[100^{*} \mathrm{Mg} /\left(\mathrm{Mg}+\sum \mathrm{Fe}\right)\right]$ varies from 87.3 to 93.4. Representative mineral compositions are presented in Table 1.

The fine-grained groundmass is mainly composed of calcite, olivine, phlogopite, magnesiochromite, Ti-magnetite, perovskite and apatite (Fig. 2c). Spinel exhibits distinctive atoll structures, in which euhedral cores of compositionally zoned magnesiochromite are surrounded by concentrically arranged zones of silicate material, which are in turn surrounded by magnetite. Very similar atoll spinels have been reported in other kimberlites ${ }^{6}$. Perovskite crystals are up to $100 \mu \mathrm{m}$ across and perfectly octahedral (Fig. 2c). They formed in the groundmass and are also included in some olivine rims. Abundant anhedral calcite crystallized interstitially to other groundmass phases and makes up 10-12 modal\% of the rocks. The association of xenocrystic and phenocrystic olivine and phlogopite macrocrysts set in a matrix containing perovskite,



Figure 1 | Localities of $\mathbf{1 2 0}$ Ma old Gondwanan kimberlites.

(a) Reconstruction of Gondwana at $\sim 120 \mathrm{Ma}$ (adapted from Veevers et al. ${ }^{40}$ ). The nPCM kimberlite occurrence is marked as a red dot. Other Cretaceous Gondwanan kimberlites 5,27,30-33,41,42 are shown as smaller green dots surrounded by a dashed line, broadly defining a vast Gondwanan, Cretaceous kimberlite province, which is extended into Antarctica by the newly discovered nPCM kimberlites; (b) Enlargement of the area surrounding the $\mathrm{nPCM}$ kimberlite localities, showing the location of samples 77063, 77081 and 77082 from Mt Meredith (red/white cross). When combined with the locations of nearby Cretaceous alkaline ultramafic and mafic rocks and carbonatites 9,10,15 (blue/white crosses), they form a linear feature parallel to the Lambert Graben, in which the Lambert Glacier flows. The length of the scale bar in $\mathbf{b}$ is $50 \mathrm{~km}$.

spinel, apatite and carbonate is a distinctive feature of kimberlites $^{4,7}$. Notably, clinopyroxene does not occur as phenocrysts nor in the groundmass, precluding classification of these samples as ultramafic lamprophyres (UML) ${ }^{8}$, examples of which have been reported from other localities in the nPCM region $^{9-12}$.

Whole rock geochemistry. The rocks are ultrabasic (29.2 to 32.1 wt $\% \mathrm{SiO}_{2}$ ) and have high $\mathrm{MgO}(19.1-27.3 \mathrm{wt} \%), \mathrm{CaO}(10.9-28.8$ wt $\%), \mathrm{CaO} / \mathrm{Al}_{2} \mathrm{O}_{3}(2.7-2.9)$ and $\mathrm{CO}_{2}(5.3-9.0$ wt\%), but low $\mathrm{Al}_{2} \mathrm{O}_{3}$ contents (3.8-6.5 wt\%), reflecting the observed olivine- and calcite-rich mineralogy. Large ranges in $\mathrm{K}_{2} \mathrm{O}(1.3-2.8 \mathrm{wt} \%)$ and $\mathrm{P}_{2} \mathrm{O}_{5}$ (0.59-0.89 wt\%) contents mainly reflect varying modal abundances of phlogopite and apatite, respectively. $\mathrm{Na}_{2} \mathrm{O}$ 
contents are very low $(<0.15 \mathrm{wt} \%)$. On a plot of bulk $\mathrm{SiO}_{2} / \mathrm{MgO}$ versus $\mathrm{MgO} / \mathrm{CaO}$ (Fig. 3a), the samples lie within a field of representative kimberlites ${ }^{6}$. Mesozoic UML from nearby Beaver



Figure 2 | Petrographic features of the Antarctic kimberlites. (a-c) Plain light photomicrographs of the Antarctic kimberlites (a,b and $\mathbf{c}$ - samples 77081, 77063 and 77082, respectively) showing porphyritic texture and olivine alignment. Olivine (ol) crystals are set in a fine- to coarse-grained groundmass, consisting of phlogopite (phl), calcite (cc), perovskite (pr), apatite and magnetite. Scale bar is $2 \mathrm{~mm}$ long in $\mathbf{a}$ and $\mathbf{b}$ and $20 \mu \mathrm{m}$ long in c. (d) Backscattered electron image of zoned olivine crystal with euhedral inclusions of high-Ca (cpx; upper left insert) and low-Ca (opx; lower right insert) pyroxenes in the resorbed core (sample 77082). Scale bar is $100 \mu \mathrm{m}$ long in the main panel, $10 \mu \mathrm{m}$ long in the upper left insert and $30 \mu \mathrm{m}$ long in the lower right insert.
Lake ${ }^{12}$ have higher $\mathrm{SiO}_{2} / \mathrm{MgO}$ values $(\geq 2)$ and are mostly outside the kimberlite field.

Incompatible trace element concentrations tend to be high (generally $>100 \times$ Primitive Mantle ${ }^{13}$ or more). For example, Rare Earth Element (REE) patterns are strongly light REEenriched $\left([\mathrm{La} / \mathrm{Yb}]_{\mathrm{n}}=74-136\right)$, similar to kimberlites from other continents. $\mathrm{K}, \mathrm{Pb}, \mathrm{Zr}, \mathrm{Hf}$ and $\mathrm{Ti}$ are depleted relative to trace elements of similar incompatibility ( $\mathrm{La}, \mathrm{Ce}, \mathrm{Sm}, \mathrm{Eu}$ and $\mathrm{Gd}$ ) (Fig. 3b). The abundances of all measured incompatible trace elements and the general form of the Primitive Mantle normalized patterns match very closely kimberlites from other world-wide localities (Fig. 3b). Full whole rock analyses for the current samples are reported in Table 2.

Radiometric ages of the samples. Perovskite $\mathrm{U}-\mathrm{Pb}$ dating by the laser ablation inductively coupled plasma mass spectrometry (LA-ICP-MS) method yielded apparent ages of $113 \pm 13 \mathrm{Ma}(2 \sigma)$ (77063), $125 \pm 8 \mathrm{Ma}$ (77081) and $121 \pm 13 \mathrm{Ma}$ (77082, see Methods section U-Pb LA-ICP-MS dating of perovskite). Assuming the perovskites are coeval, we obtain a weighted age of $122 \pm 6 \mathrm{Ma}$. This is supported by a $117 \pm 1 \mathrm{Ma} \mathrm{Rb}-\mathrm{Sr}$ age for phlogopite from 77063 (Table 4). On the basis of these ages, it is likely that that samples 77081 and 77082, from boulders within till are related in terms of age, to the kimberlite from which 77063 was sampled. An origin from the same kimberlite pipe, however, is unlikely given the diversity in initial $\mathrm{Sr}, \mathrm{Nd}, \mathrm{Hf}$ and $\mathrm{Pb}$ isotope ratios $\left({ }^{87} \mathrm{Sr} /{ }^{86} \mathrm{Sr} 0.7042-0.7054, \varepsilon_{\mathrm{Nd}}+1.9\right.$ to $-2.1, \varepsilon_{\mathrm{Hf}}+4.6$ to $-5.5,{ }^{206} \mathrm{~Pb} /{ }^{204} \mathrm{~Pb} 18.04-18.42$, see Tables $\left.3-5\right)$. The bulk rock ${ }^{87} \mathrm{Sr} /{ }^{86} \mathrm{Sr}$ for $77063(0.7054 \pm 1)$ is supported by in situ $\mathrm{Sr}$ isotope data for perovskite $(0.70539 \pm 12$, see Supplementary Fig. S1). These radiogenic isotope signatures are intermediate between those established for Group I and transitional kimberlites from southern Africa ${ }^{14}$.

Table 1 | Representative electronprobe microanalyzer analyses of phases in the three samples.

\begin{tabular}{|c|c|c|c|c|c|c|c|c|c|c|c|c|c|c|c|}
\hline & \multicolumn{5}{|c|}{77081} & \multicolumn{9}{|c|}{77082} & \multirow{2}{*}{$\begin{array}{c}77063 \\
\text { OLIVINE }\end{array}$} \\
\hline & OLIVINE & OLIVINE & SPINEL & SPINEL & SPINEL & $\begin{array}{c}\text { OLIVINE } \\
\text { CORE }\end{array}$ & $\begin{array}{c}\text { OLIVINE } \\
\text { RIM }\end{array}$ & PHLOG & PHLOG & SPINEL & SPINEL & SPINEL & PVSK & PVSK & \\
\hline $\mathrm{SiO}_{2}$ & 40.84 & 40.75 & 0.16 & 0.15 & 0.16 & 38.19 & 38.00 & 37.75 & 38.03 & 0.12 & 0.08 & 0.09 & 0.11 & 0.21 & 40.56 \\
\hline $\mathrm{TiO}_{2}$ & 0.04 & 0.02 & 1.45 & 1.57 & 1.45 & 0.01 & 0.01 & 0.75 & 0.81 & 0.71 & 0.79 & 0.63 & 53.54 & 52.66 & 0.00 \\
\hline $\mathrm{Al}_{2} \mathrm{O}_{3}$ & 0.04 & 0.06 & 24.71 & 28.80 & 25.94 & 0.03 & 0.01 & 17.32 & 16.50 & 44.88 & 56.86 & 52.51 & 0.42 & 0.57 & 0.03 \\
\hline $\mathrm{Cr}_{2} \mathrm{O}_{3}$ & 0.07 & 0.06 & 36.44 & 31.94 & 35.24 & 0.00 & 0.00 & 0.02 & 0.00 & 16.79 & 1.68 & 8.93 & 0.00 & 0.00 & 0.04 \\
\hline $\mathrm{FeO}$ & 10.55 & 10.80 & 20.15 & 20.24 & 19.32 & 23.76 & 23.81 & 4.52 & 5.15 & 17.88 & 18.66 & 16.20 & 1.81 & 2.44 & 10.53 \\
\hline $\mathrm{MnO}$ & 0.17 & 0.17 & 0.00 & 0.00 & 0.00 & 0.32 & 0.31 & 0.10 & 0.13 & 0.00 & 0.10 & 0.00 & 0.03 & 0.00 & 0.17 \\
\hline $\mathrm{MgO}$ & 48.82 & 48.70 & 15.29 & 16.05 & 15.51 & 38.25 & 38.41 & 23.68 & 24.58 & 18.66 & 20.59 & 19.82 & 0.00 & 0.00 & 48.71 \\
\hline $\mathrm{NiO}$ & 0.36 & 0.40 & 0.23 & 0.20 & 0.22 & 0.05 & 0.08 & 0.00 & 0.00 & 0.22 & 0.14 & 0.18 & 0.00 & 0.00 & 0.27 \\
\hline $\mathrm{CaO}$ & 0.11 & 0.13 & 0.01 & 0.01 & 0.00 & 0.05 & 0.10 & 0.02 & 0.12 & 0.04 & 0.04 & 0.11 & 36.86 & 37.49 & 0.09 \\
\hline $\mathrm{Na}_{2} \mathrm{O}$ & 0.01 & 0.00 & 0.01 & 0.00 & 0.00 & 0.00 & 0.00 & 0.36 & 0.50 & 0.03 & 0.00 & 0.00 & 0.42 & 0.25 & 0.00 \\
\hline $\mathrm{K}_{2} \mathrm{O}$ & 0.01 & 0.02 & 0.00 & 0.01 & 0.01 & 0.01 & 0.01 & 9.97 & 8.24 & 0.00 & 0.01 & 0.01 & 0.09 & 0.07 & 0.00 \\
\hline $\mathrm{P}_{2} \mathrm{O}_{5}$ & 0.00 & 0.05 & 0.00 & 0.00 & 0.01 & 0.06 & 0.01 & 0.00 & 0.01 & 0.00 & 0.01 & 0.00 & 0.01 & 0.04 & 0.03 \\
\hline Total & 101.02 & 101.15 & 98.44 & 98.97 & 97.85 & 100.72 & 100.75 & 94.48 & 94.06 & 99.33 & 98.94 & 98.49 & 93.28 & 93.74 & 100.40 \\
\hline cations/O & 4.000 & 4.000 & 4.000 & 4.000 & 4.000 & 4.000 & 4.000 & 11.000 & 11.000 & 4.000 & 4.000 & 4.000 & 3.000 & 3.000 & 4.000 \\
\hline $\mathrm{Si}$ & 0.996 & 0.994 & 0.005 & 0.005 & 0.005 & 0.993 & 0.989 & 2.711 & 2.727 & 0.003 & 0.002 & 0.003 & 0.003 & 0.005 & 0.995 \\
\hline $\mathrm{Ti}$ & 0.001 & 0.000 & 0.034 & 0.036 & 0.034 & 0.000 & 0.000 & 0.040 & 0.043 & 0.015 & 0.016 & 0.013 & 0.982 & 0.964 & 0.000 \\
\hline $\mathrm{Al}$ & 0.001 & 0.002 & 0.901 & 1.025 & 0.943 & 0.001 & 0.000 & 1.466 & 1.395 & 1.474 & 1.783 & 1.674 & 0.012 & 0.016 & 0.001 \\
\hline $\mathrm{Cr}$ & 0.001 & 0.001 & 0.892 & 0.762 & 0.860 & 0.000 & 0.000 & 0.001 & 0.000 & 0.370 & 0.035 & 0.191 & 0.000 & 0.000 & 0.001 \\
\hline $\mathrm{Fe}$ & 0.215 & 0.220 & 0.521 & 0.511 & 0.498 & 0.517 & 0.518 & 0.271 & 0.309 & 0.416 & 0.415 & 0.366 & 0.037 & 0.050 & 0.216 \\
\hline $\mathrm{Mn}$ & 0.004 & 0.003 & 0.000 & 0.000 & 0.000 & 0.007 & 0.007 & 0.006 & 0.008 & 0.000 & 0.002 & 0.000 & 0.001 & 0.000 & 0.004 \\
\hline $\mathrm{Mg}$ & 1.774 & 1.770 & 0.705 & 0.722 & 0.713 & 1.482 & 1.490 & 2.535 & 2.627 & 0.775 & 0.816 & 0.798 & 0.000 & 0.000 & 1.781 \\
\hline $\mathrm{Ni}$ & 0.007 & 0.008 & 0.006 & 0.005 & 0.005 & 0.001 & 0.002 & 0.000 & 0.000 & 0.005 & 0.003 & 0.004 & 0.000 & 0.000 & 0.005 \\
\hline $\mathrm{Ca}$ & 0.003 & 0.003 & 0.000 & 0.000 & 0.000 & 0.001 & 0.003 & 0.001 & 0.009 & 0.001 & 0.001 & 0.003 & 0.963 & 0.978 & 0.002 \\
\hline $\mathrm{Na}$ & 0.001 & 0.000 & 0.000 & 0.000 & 0.000 & 0.000 & 0.000 & 0.050 & 0.069 & 0.001 & 0.000 & 0.000 & 0.020 & 0.012 & 0.000 \\
\hline K & 0.000 & 0.001 & 0.000 & 0.000 & 0.000 & 0.000 & 0.000 & 0.914 & 0.754 & 0.000 & 0.000 & 0.000 & 0.003 & 0.002 & 0.000 \\
\hline$P$ & 0.000 & 0.001 & 0.000 & 0.000 & 0.000 & 0.001 & 0.000 & 0.000 & 0.001 & 0.000 & 0.000 & 0.000 & 0.000 & 0.001 & 0.000 \\
\hline Total & 3.003 & 3.003 & 3.065 & 3.066 & 3.060 & 3.004 & 3.010 & 7.996 & 7.943 & 3.061 & 3.073 & 3.053 & 2.020 & 2.028 & 3.005 \\
\hline $\mathrm{Mg}^{\#}$ & 89.18 & 88.93 & 57.48 & 58.56 & 58.87 & 74.15 & 74.19 & 90.33 & 89.49 & 65.03 & 66.29 & 68.55 & 0.00 & 0.00 & 89.18 \\
\hline
\end{tabular}



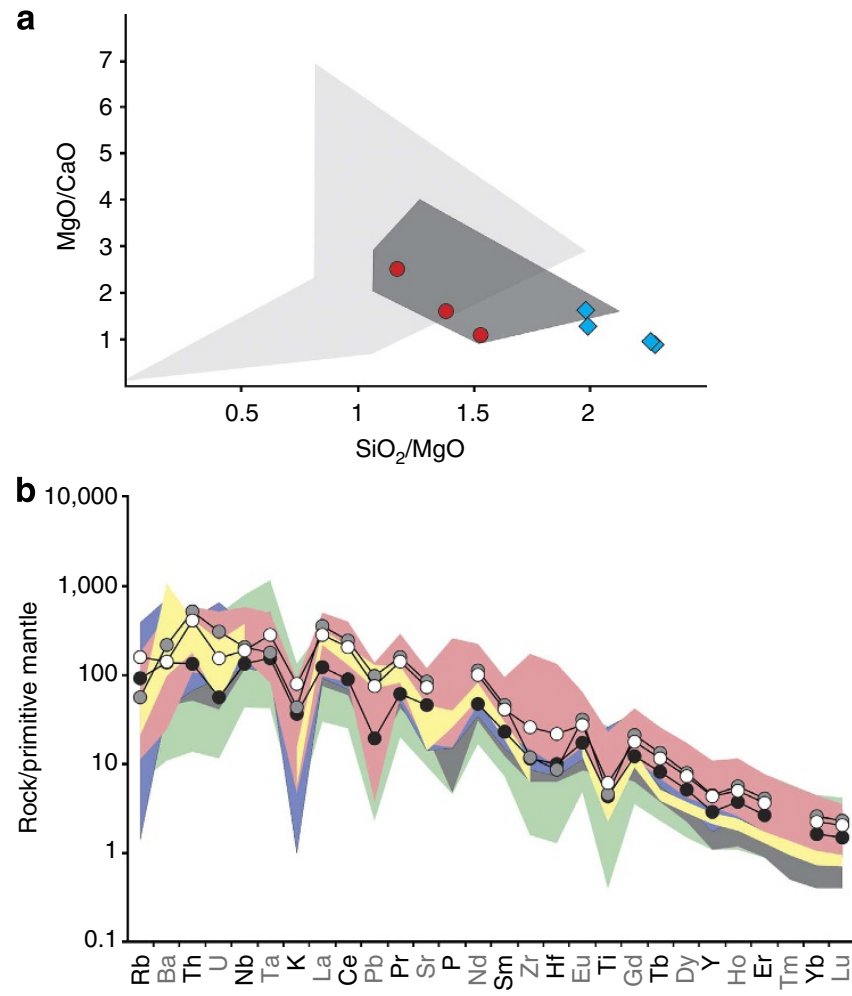

Figure 3 | Whole rock geochemical characteristics of the Antarctic

kimberlites. (a) Plot of whole-rock $\mathrm{SiO}_{2} / \mathrm{MgO}$ versus $\mathrm{MgO} / \mathrm{CaO}$ for the samples 77081, 77063 and 77082 (red dots) compared with Mitchell's ${ }^{6}$ field for representative, average kimberlites (dark grey shading), for extreme kimberlite compositions (light grey shading) and the UML from nearby Beaver Lake (Jetty Peninsula) ${ }^{12}$ (blue diamonds). (b) Primitivemantle normalized ${ }^{13}$, extended trace element plot of the three nPCM kimberlites (77081, black circles; 77063, white circles; and 77082, grey circles) compared with the range of values from a representative suite of 167 kimberlites from Africa (pink), Canada (yellow), Greenland (grey), India (indigo) and Siberia (green) ${ }^{43-51}$.

\section{Discussion}

Ultramafic-mafic alkaline, carbonatitic and kimberlite-like rocks of similar age have been reported from elsewhere in the nPCM region, including Else Platform, Radok Lake and on the Fischer Massif, adjacent to the Lambert rift $^{9,10,15}$. These rocks were classified as UML (alnöites), alkaline picrites, ultrabasic foidites, trachybasalts and carbonatite-kimberlites. In particular, Egorov et al. ${ }^{16}$ reported the 'first Antarctic occurrence of a dike kimberlite' in the nPCM, inferred to be Early Cretaceous in age. However, samples from this dyke are significantly different from the current samples in that olivine macrocrysts (containing mantle-derived clinopyroxene and orthopyroxene inclusions Fig. 2d), garnet xenocrysts, ilmenite and perovskite are not reported. However, globular 'syngenetic calcite carbonatite schlieren' were present. In addition, the dyke is compositionally outside the range for kimberlites with low $\mathrm{MgO}$ (17 wt\%) and $\mathrm{Ni}$ $(480 \mathrm{ppm})$, reflecting the low modal olivine. We argue that this dyke is not a bona fide kimberlite, but more akin to a carbonatite magma that fractionated into a calcite-rich component and an apatite + magnetite + olivine component.

The bona fide kimberlites described here and the other nPCM ultrabasic rock correlates appear to define a N-S linear feature extending $150 \mathrm{~km}$ along the margin of the Lambert rift (Fig. 1b). Interestingly, the UML occur in the northern part of the region (mainly around Beaver Lake) $^{9-12}$, whereas the current kimberlites

\begin{tabular}{|c|c|c|c|}
\hline & 77081 & 77082 & 77063 \\
\hline $\mathrm{SiO}_{2}$ & 32.05 & 29.19 & 29.47 \\
\hline $\mathrm{TiO}_{2}$ & 1.54 & 1.64 & 2.23 \\
\hline $\mathrm{Al}_{2} \mathrm{O}_{3}$ & 3.76 & 6.53 & 4.63 \\
\hline $\mathrm{FeO}$ & 9.94 & 9.23 & 9.52 \\
\hline $\mathrm{MnO}$ & 0.13 & 0.16 & 0.16 \\
\hline $\mathrm{MgO}$ & 27.29 & 19.12 & 21.42 \\
\hline $\mathrm{CaO}$ & 10.89 & 17.49 & 13.39 \\
\hline $\mathrm{Na}_{2} \mathrm{O}$ & 0.01 & 0.15 & 0.11 \\
\hline $\mathrm{K}_{2} \mathrm{O}$ & 1.30 & 1.56 & 2.81 \\
\hline $\mathrm{P}_{2} \mathrm{O}_{5}$ & 0.59 & 0.85 & 0.89 \\
\hline $\mathrm{H}_{2} \mathrm{O}^{+}$ & 6.50 & 6.44 & 3.94 \\
\hline $\mathrm{H}_{2} \mathrm{O}^{-}$ & 0.39 & 0.69 & \\
\hline $\mathrm{CO}_{2}$ & 5.26 & 6.17 & 8.98 \\
\hline Total & 99.46 & 98.53 & 97.56 \\
\hline $\mathrm{Li}$ & 19.8 & 13.6 & 10.9 \\
\hline Sc & 15.6 & 15.8 & 16.8 \\
\hline V & 141 & 150 & 148 \\
\hline Co & 88 & 63 & 81 \\
\hline $\mathrm{Ni}$ & 979 & 360 & 601 \\
\hline $\mathrm{Cu}$ & 49 & 41 & 39 \\
\hline $\mathrm{Zn}$ & 88 & 97 & 73 \\
\hline $\mathrm{Ga}$ & 10.1 & 15.3 & 9.5 \\
\hline $\mathrm{Cd}$ & 0.06 & 0.07 & 0.09 \\
\hline Sn & 2.15 & 1.55 & 1.94 \\
\hline $\mathrm{Sb}$ & 0.04 & 0.12 & 0.17 \\
\hline Cs & 6.78 & 2.63 & 7.54 \\
\hline $\mathrm{Rb}$ & 57.1 & 34.9 & 100.7 \\
\hline $\mathrm{Ba}$ & 947 & 1484 & 987 \\
\hline Th & 11.1 & 43.2 & 34.3 \\
\hline U & 1.17 & 6.37 & 3.22 \\
\hline $\mathrm{Nb}$ & 94 & 146 & 134.4 \\
\hline Ta & 6.24 & 7.28 & 11.4 \\
\hline La & 82.4 & 240 & 193 \\
\hline $\mathrm{Ce}$ & 155 & 425 & 356 \\
\hline $\mathrm{Pb}$ & 3.56 & 17.7 & 13.6 \\
\hline $\operatorname{Pr}$ & 16.9 & 43.5 & 38.5 \\
\hline $\mathrm{Sr}$ & 950 & 1759 & 1504 \\
\hline $\mathrm{Nd}$ & 64.1 & 151 & 135 \\
\hline $\mathrm{Sm}$ & 10.2 & 20.0 & 18.0 \\
\hline $\mathrm{Zr}$ & 128 & 133 & 290 \\
\hline $\mathrm{Hf}$ & 3.09 & 2.69 & 6.61 \\
\hline Eu & 2.87 & 5.32 & 4.53 \\
\hline Gd & 7.14 & 12.4 & 10.6 \\
\hline $\mathrm{Tb}$ & 0.87 & 1.42 & 1.23 \\
\hline Dy & 3.83 & 5.83 & 5.36 \\
\hline Y & 13.3 & 20.4 & 19.7 \\
\hline Ho & 0.61 & 0.91 & 0.81 \\
\hline $\mathrm{Er}$ & 1.28 & 1.94 & 1.73 \\
\hline $\mathrm{Yb}$ & 0.80 & 1.27 & 1.10 \\
\hline Lu & 0.11 & 0.17 & 0.15 \\
\hline
\end{tabular}

and the carbonatite-kimberlite reported by Belyatsky et al. ${ }^{15}$ occur in the southern part. This may reflect progressive stages of development of the Lambert rift, with the UML representing a greater extent of rifting in the north, more erosion of the base of the lithosphere leading to melting at shallower subcontinental lithospheric levels, relative to the kimberlites in the south. Similar models have been suggested in the Ailik Bay rift ${ }^{17}$, and in the currently active rift in the western branch of the East African Rift system $^{18}$

Kimberlites and related alkaline igneous rocks occur in all major Gondwanan continents (Africa, India, South America and 
Table 3 | Rb-Sr and Sm-Nd isotope results.

\begin{tabular}{|c|c|c|c|c|c|c|}
\hline $\mathrm{Rb}(\mathrm{ppm})$ & 245.0 & 51.5 & 91.5 & 37.09 & 55.37 & 25.0 \\
\hline${ }^{87} \mathrm{Sr} /{ }^{86} \mathrm{Sr}$ & 0.70560 & 0.70638 & 0.70434 & 0.70732 & 0.70519 & 0.70600 \\
\hline Sm (ppm) & 21.86 & 16.22 & 17.46 & 3.11 & 9.81 & 22.44 \\
\hline $\mathrm{Nd}(\mathrm{ppm})$ & 144.8 & 128.5 & 104.7 & 22.55 & 63.32 & 177.9 \\
\hline$\varepsilon_{\mathrm{Nd}}$ & -3.8 & -3.9 & 0.43 & 0.06 & -2.98 & -2.63 \\
\hline${ }^{87} \mathrm{Sr} /{ }^{86} \mathrm{Sr}(t)$ & 0.7054 & 0.7054 & 0.7042 & 0.7042 & 0.7050 & 0.7053 \\
\hline$\varepsilon_{\mathrm{Nd}}(t)$ & -2.2 & -2.1 & 1.9 & 1.8 & -1.4 & -0.8 \\
\hline
\end{tabular}

\begin{tabular}{|c|c|c|c|c|}
\hline Sample & Rb ppm & Sr ppm & ${ }^{87} \mathrm{Rb} /{ }^{86} \mathrm{Sr}$ & ${ }^{87} \mathrm{Sr} /{ }^{86} \mathrm{~S}$ \\
\hline 77063 PHLOG 1 & 233.2 & 98.6 & 6.848 & 0.71679 \\
\hline 77063 PHLOG 2 & 216.2 & 84.9 & 7.374 & 0.71777 \\
\hline
\end{tabular}

Australia), but have not previously been reported from Antarctica. Kimberlite emplacement ages show well-developed clustering throughout the Mesoproterozoic, early Paleozoic, Mesozoic and Cenozoic ${ }^{5}$. In the Mesozoic, major emplacement events occurred 240, 145, 120, 85 and $73 \mathrm{Ma}$ ago. The ca. $120 \mathrm{Ma}$ episode was distributed particularly widely across the Gondwanan continents, and discovery of $120 \mathrm{Ma}$ kimberlites in East Antarctica further extends this vast Cretaceous kimberlite province (Fig. 1a).

At $120 \mathrm{Ma}$ India and amalgamated Antarctica-Australia had already begun to drift apart, with early sea-floor spreading forming the proto-Indian Ocean ${ }^{19}$. The graben, on the margin of which the current kimberlites were emplaced, is a $700 \mathrm{~km}$ long zone of thinned continental crust believed to represent either a failed, trans-tensional basin that was activated $120 \mathrm{Ma}$ ago during early extension associated with break-up of India and Antarctica-Australia ${ }^{20,21}$, or an accommodation zone related to a Carboniferous-Permian intracontinental rift between India and Antarctica, which was reactivated in the Cretaceous during continental dispersion ${ }^{22}$. Whichever the case, the nPCM kimberlites (and related alkali rocks of similar age at nearby locations $s^{10,12,15}$ - Fig. 1) are most likely a magmatic expression of reactivation of pre-existing lithospheric discontinuities associated with the Lambert Graben during opening of the proto-Indian ocean. Kent ${ }^{23}$ reported orangeites of age 109-116 Ma peripheral to the Bay of Bengal, India (Damodar Valley), which may relate to the same Cretaceous kimberlite province. Jelsma et al. ${ }^{5}$ have shown that the time intervals in which kimberlite emplacement events were concentrated, coincided with fundamental plate reorganizations, such as supercontinent break-up. Thus, as well as constituting the first-known bona fide Antarctic kimberlite occurrence, the location of the nPCM kimberlites is consistent with models relating kimberlite distribution to reactivation of major trans-lithospheric structures during continental scale tectonic events ${ }^{5}$, and likely marks the onset of the reactivation of continental rifting zones, that is, similar to suggestions for other rift-related continental mantle-derived magmas such as carbonatites, UML and kamafugites (this study and refs 17,18 ).

\begin{tabular}{|lccc|}
\hline \multicolumn{4}{|l}{ Table 5 I Lu-Hf and U-Pb isotope results. } \\
Sample & $\mathbf{7 7 0 6 3}$ & $\mathbf{7 7 0 8 1 A}$ & $\mathbf{7 7 0 8 2 A}$ \\
\hline $\mathrm{Lu}(\mathrm{ppm})$ & 0.146 & 0.089 & 0.123 \\
$\mathrm{Hf}(\mathrm{ppm})$ & 6.07 & 1.97 & 3.19 \\
${ }^{176} \mathrm{Lu} /{ }^{177} \mathrm{Hf}$ & 0.00343 & 0.00644 & 0.00547 \\
${ }^{176} \mathrm{Hf} /{ }^{177} \mathrm{Hf}$ & 0.282550 & 0.282843 & 0.282808 \\
$\varepsilon_{\mathrm{Hf}}$ & -8.17 & 2.51 & 1.27 \\
$\varepsilon_{\mathrm{Hf}}(t)$ & -5.5 & 4.6 & 3.5 \\
$\mathrm{U}(\mathrm{ppm})$ & 3.41 & 1.06 & 6.22 \\
$\mathrm{~Pb}(\mathrm{ppm})$ & 14.83 & 2.77 & 15.88 \\
$238 \mathrm{U} / 204 \mathrm{~Pb}$ & 14.78 & 25.02 & 25.26 \\
$232 \mathrm{Th} /{ }^{204} \mathrm{~Pb}$ & 162.2 & 245.3 & 177.1 \\
${ }^{206} \mathrm{~Pb} /{ }^{204} \mathrm{~Pb}$ & 18.424 & 18.895 & 18.518 \\
${ }^{207} \mathrm{~Pb} /{ }^{204} \mathrm{~Pb}$ & 15.625 & 15.618 & 15.629 \\
${ }^{208} \mathrm{~Pb} /{ }^{204} \mathrm{~Pb}$ & 39.344 & 40.128 & 39.470 \\
${ }^{206} \mathrm{~Pb} /{ }^{204} \mathrm{~Pb}(t)$ & 18.15 & 18.42 & 18.04 \\
${ }^{207} \mathrm{~Pb} /{ }^{204} \mathrm{~Pb}(t)$ & 15.61 & 15.60 & 15.61 \\
${ }^{208} \mathrm{~Pb} /{ }^{204} \mathrm{~Pb}(t)$ & 38.34 & 38.67 & 38.42 \\
\hline
\end{tabular}

Thus, the Antarctic kimberlites and previously reported UML as well as other alkaline volcanics in the nPCM region potentially provide rare insights into large-scale tectonic mantle processes during the Cretaceous.

\section{Methods}

Electronprobe microanalysis. Constituent mineral phases in the samples were analysed for major and minor elements using a Cameca SX-50 WDS electronprobe microanalyser at Macquarie University. The accelerating voltage was $15 \mathrm{kV}$ and beam current was $20 \mathrm{nA}$. Count times varied from $20 \mathrm{~s}$ on major elements to $60 \mathrm{~s}$ on minor elements. Calibration was performed on natural mineral standards. Representative data is presented in Table 1.

X-ray fluorescence analysis. Whole rock major and minor element abundances were determined on powdered samples using X-ray fluorescence (XRF) microscopy, at Macquarie University (Table 2).

Solution - ICP-MS analysis. Trace element abundances in the chilled margins were measured by solution - ICP-MS at the Australian National University (ANU) following procedures similar to those described by Norman et al. ${ }^{24}$ (Table 2).

Isotopic analyses. $\mathrm{Rb}-\mathrm{Sr}$ and $\mathrm{Sm}-\mathrm{Nd}$ isotope analyses were performed on leachate-residue pairs. Sample 77063 (105 mg, fine crush) was leached with cold $2 \mathrm{M} \mathrm{HCl}(12 \mathrm{~h})$, whereas rock powders for $77081 \mathrm{~A}$ and $77082 \mathrm{~A}$ were leached with cold $6 \mathrm{M} \mathrm{HCl}$. After removal of the clear solution, the residues were dried and re-weighed to determine weight loss during acid leaching. The residues were dissolved at low pressure using $\mathrm{HF} / \mathrm{HNO}_{3}$ and $\mathrm{HCl}$. Following preliminary semi-quantitative trace element analysis, all fractions were spiked with ${ }^{85} \mathrm{Rb}-{ }^{84} \mathrm{Sr}$ 
and ${ }^{149} \mathrm{Sm}-{ }^{150} \mathrm{Nd}$ tracers, followed by extraction of Rb, Sr and LREE using conventional cation exchange and EICHROM Sr and $\mathrm{LN}$ resins ${ }^{25}$. Total analytical blanks $(<0.1 \mathrm{ng})$ were negligible. Isotopic analyses were carried out on a NU Plasma multi-collector ICP-MS coupled to a CETAC Aridus desolvator. As part of an online iterative spike removal/mass bias correction procedure, instrumental mass bias was corrected by internal normalization to ${ }^{88} \mathrm{Sr} /{ }^{86} \mathrm{Sr}=8.37521$ and ${ }^{146} \mathrm{Nd} /{ }^{145} \mathrm{Nd}=2.0719425$ (equivalent to ${ }^{146} \mathrm{Nd} /{ }^{144} \mathrm{Nd}=0.7219$ (ref. 26)); data are reported relative to SRM987 $=0.710230$ and La Jolla $\mathrm{Nd}=0.511860$. Typical inrun precisions (two standard errors) are \pm 0.000020 (Sr) and $\leq \pm 0.000010(\mathrm{Nd})$, whereas external $(2 \sigma)$ precisions - based on rock standards - are $\pm 0.000020(\mathrm{Nd})$ and \pm 0.000040 (Sr). External precision $(2 \sigma)$ for ${ }^{87} \mathrm{Rb} /{ }^{86} \mathrm{Sr}$ and ${ }^{147} \mathrm{Sm} /{ }^{144} \mathrm{Nd}$ is $\pm 0.5 \%$ and $\pm 0.2 \%$, respectively. ${ }^{147} \mathrm{Sm} /{ }^{144} \mathrm{Nd}$ and ${ }^{143} \mathrm{Nd} /{ }^{144} \mathrm{Nd}$ in modern CHUR is 0.1967 and 0.512638 . Initial ${ }^{87} \mathrm{Sr} /{ }^{86} \mathrm{Sr}(\mathrm{t})$ and $\varepsilon_{\mathrm{Nd}}(\mathrm{t})$ were calculated for $t=120 \mathrm{Ma}$. Results for standards ( \pm 2 s.d.) are as follows: BCR-2 $(n=2)$; Rb $46.8 \mathrm{ppm}$, Sr $339 \mathrm{ppm},{ }^{87} \mathrm{Rb} /{ }^{86} \mathrm{Sr} 0.400,{ }^{87} \mathrm{Sr} /{ }^{86} \mathrm{Sr} 0.70502, \mathrm{Sm} 6.48 \mathrm{ppm}$, Nd $28.32 \mathrm{ppm},{ }^{147} \mathrm{Sm} /{ }^{144} \mathrm{Nd} 0.1382,{ }^{143} \mathrm{Nd} /{ }^{144} \mathrm{Nd} 0.512629 ; 0.512640 \pm 17$ (mean of 21 runs of BCR-2 in 2010), $0.705015 \pm 34$ (mean of 8 runs of BCR-2 in 2010-2011: JNd-1; $0.512114 \pm 23$ (mean of 9 runs in 2010); BHVO-2 $0.512992 \pm 17$ (mean of 6 runs in 2010). Results are consistent with Thermal Ionisation Mass Spectrometry (TIMS) reference values. Uncertainties in initial ratios are: ${ }^{87} \mathrm{Sr} /{ }^{86} \mathrm{Sr} \pm 0.00010 ; \varepsilon_{\mathrm{Nd}}$ \pm 0.5 units. The decay constants are: ${ }^{87} \mathrm{Rb} 1.4210^{-11 / y r},{ }^{147} \mathrm{Sm} 6.5410^{-12} / \mathrm{yr}$.

$\mathrm{Rb}-\mathrm{Sr}$ dating of megacrystic phlogopite from sample 77063 was done on euhedral $(1-3 \mathrm{~mm})$ mineral flakes. Two handpicked fractions $(2-4 \mathrm{mg})$ were cleaned in $0.1 \mathrm{M} \mathrm{HNO}_{3}$, spiked with ${ }^{87} \mathrm{Rb}_{-}{ }^{84} \mathrm{Sr}$ tracer and dissolved on a hotplate. Sr was extracted and purified using two passes over a small $(0.1 \mathrm{ml})$ column of EICHROM Sr-resin $(50-100 \mu \mathrm{m})$. Rb was extracted using cation resin chromatography ( $4 \mathrm{ml}$ of AG50-X8, 200-400 mesh). Sr isotope data were measured as described above, whereas $\mathrm{Rb}$ isotope dilution analyses were done using the $\mathrm{Zr}$-doping method ${ }^{28}$. Rb-Sr mica ages were derived by combining each phlogopite analysis with the $\mathrm{Rb}-\mathrm{Sr}$ data for $77063 \mathrm{~L}$ and $\mathrm{R}$; calculations were done in ISOPLOT ${ }^{29}$. External precision (2 s.d.) for ${ }^{87} \mathrm{Rb} /{ }^{86} \mathrm{Sr}$ is $0.5 \%$, and for ${ }^{87} \mathrm{Sr} /{ }^{86} \mathrm{Sr}$ is $0.01 \% .{ }^{87} \mathrm{Sr} /{ }^{86} \mathrm{Sr}$ is reported relative to SRM987 $=0.710230$. Rb-Sr model ages $( \pm 2$ s.d.) for glauconite standard GLO-1 $(89.3 \pm 0.8 \mathrm{Ma}, n=16$ over 7 years, assumed initial $\left.{ }^{87} \mathrm{Sr} /{ }^{86} \mathrm{Sr} 0.7074\right)$ and SRM607 feldspar (1424 $\pm 7 \mathrm{Ma}, n=11$ over 7 years, assumed initial ${ }^{87} \mathrm{Sr} /{ }^{86} \mathrm{Sr} 0.705$ ) obtained using the same spike and techniques as those used for the phlogopites are consistent with Ar-Ar reference ages. Biotite GA1550 from Mount Dromedary (SE Australia) yields a $\mathrm{Rb}-\mathrm{Sr}$ isochron age of $98.0 \pm 0.3 \mathrm{Ma}(n=9,0.70445 \pm 6$, MSWD (mean square weighted deviation) 1.6), consistent with Ar-Ar ages of $98.5 \pm 0.8 \mathrm{Ma}^{32}$ and $98.8 \pm 0.5 \mathrm{Ma}^{33}$. Results are given in Table 4.

Semiquantitative trace element data for leachate-residue pairs (see above) indicate that most of the Hf resides in the residue ( $>90 \%$ ), whereas Lu favours the leachates, consistent with their mineralogy and Bizimis et al. ${ }^{34}$. Overall, Lu-Hf budgets are dominated by the residue. $\mathrm{Lu}-\mathrm{Hf}$ isotope analyses were therefore done on unleached whole rock powders. After dissolution at high pressure, a 90\% split of the solutions was spiked with a ${ }^{176} \mathrm{Lu}-{ }^{180} \mathrm{Hf}$ tracer. Lu and $\mathrm{Hf}$ were isolated using a single-column technique ${ }^{35}$ and measured by Multi-Collector-ICP-MS. The smaller split was equilibrated with a ${ }^{233} \mathrm{U}-{ }^{205} \mathrm{~Pb}$ tracer, followed by extraction of $\mathrm{Pb}$ and $\mathrm{U}$ on small columns of AG1-X8 (100-200 mesh, $\mathrm{HBr}-\mathrm{HCl})$ and EICHROM TRU resin $(100-150 \mu \mathrm{m})$, respectively. $\mathrm{Pb}$ and $\mathrm{U}$ isotope ratios were measured by MC-ICP-MS ${ }^{25}$. Isotope dilution calculations for $\mathrm{U}-\mathrm{Pb}$ were done with the EarthTime Excel U-Pb data reduction module ${ }^{36} \cdot{ }^{176} \mathrm{Hf} /{ }^{177} \mathrm{Hf}$ was normalized to ${ }^{179} \mathrm{Hf} /{ }^{177} \mathrm{Hf}=0.7325$ and reported relative to JMC $475=0.282160$. Internal precision (2se) for ${ }^{176} \mathrm{Hf} /{ }^{177} \mathrm{Hf}$ is $\leq \pm 0.000008$, external precision \pm 0.000015 (2 s.d.). External precision for ${ }^{176} \mathrm{Lu} /{ }^{177} \mathrm{Hf}$ is $\pm 1 \%$. USGS standards BCR-2 and BHVO-2, analysed together with the kimberlite samples, yielded the following results: BCR-2, $0.50 \mathrm{ppm} \mathrm{Lu}, 4.94 \mathrm{ppm},{ }^{176} \mathrm{Lu} /{ }^{177} \mathrm{Hf} 0.01439,{ }^{176} \mathrm{Hf} /{ }^{177} \mathrm{Hf} 0.282868$, 0.282875 and 0.282883 ; BHVO-2, $0.274 \mathrm{ppm} \mathrm{Lu}, 4.45 \mathrm{ppm} \mathrm{Hf},{ }^{176} \mathrm{Lu} /{ }^{177} \mathrm{Hf} 0.00877$ and ${ }^{176} \mathrm{Hf} /{ }^{177} \mathrm{Hf} 0.283104$. Modern CHUR has ${ }^{176} \mathrm{Lu} /{ }^{177} \mathrm{Hf}=0.0332$ and ${ }^{176} \mathrm{Hf} /$ ${ }^{177} \mathrm{Hf}=0.282772$. The decay constant for ${ }^{176} \mathrm{Lu}$ is $1.86510^{-11} /$ year. Mass bias during $\mathrm{U}$ and $\mathrm{Pb}$ runs was corrected using internal normalisation to the natural $\mathrm{U}$ ratio and standard bracketing, respectively. External precision for ${ }^{238} \mathrm{U} /{ }^{204} \mathrm{~Pb}$ is $\pm 1 \%$ (2 s.d.). ${ }^{232} \mathrm{Th} /{ }^{204} \mathrm{~Pb}$ was derived from ${ }^{238} \mathrm{U} /{ }^{204} \mathrm{~Pb}$ measured by isotope dilution and $\mathrm{Th} / \mathrm{U}$ from quadrupole ICP-MS trace element data on different splits of the same powders; expected errors $\pm 10 \%$. External precision for $\mathrm{Pb}$ isotope data is $\approx \pm 0.1-0.2 \%$ (2s.d.); data reported are corrected for mass bias and blank $(20 \pm 10 \mathrm{pg} \mathrm{Pb})$. Uncertainties for calculated initial $\mathrm{Pb}$ isotope ratios, obtained by Monte Carlo simulation with the stated analytical uncertainties and an assumed age uncertainty of $\pm 5 \mathrm{Ma}:{ }^{206} \mathrm{~Pb} /{ }^{204} \mathrm{~Pb} \pm 0.02,{ }^{207} \mathrm{~Pb} /{ }^{204} \mathrm{~Pb} \pm 0.01,{ }^{208} \mathrm{~Pb} /{ }^{204} \mathrm{~Pb}$ $\leq \pm 0.17$. The decay constants are: ${ }^{238} \mathrm{U} 0.155125 \times 10^{-9} /$ year, ${ }^{235} \mathrm{U}$ $0.98485 \times 10^{-9} /$ year and ${ }^{232}$ Th $0.049485 \times 10^{-9} /$ year. Lu-Hf and U-Pb isotope results are given in Table 5.

U-Pb LA-ICP-MS dating of perovskite. U-Pb dating work on perovskite was performed during two analytical sessions: the first was done on polished grains in situ in blocks of fresh kimberlite samples 77063, 77081 and 77082; the second analytical session on the sample 77063 was performed on separated perovskite grains mounted in an epoxy block.

The U-Pb analyses were performed at Macquarie University using a NewWave UP-213 laser ablation microprobe attached to an Agilent 7700 ICP-MS. The analytical technique was described in ref. 37. Ablation occurs in He, permitting efficient sample transport, signal stability and reproducibility of $\mathrm{U} / \mathrm{Pb}$ fractionation. The spot size varied between $30 \mu \mathrm{m}$ for perovskite from the polished blocks and $40 \mu \mathrm{m}$ for separated grains. Because of the smaller spot sizes used on the grains from the polished blocks, the analytical uncertainties are much higher for these grains.

Samples were analysed in runs of 16 analyses comprising 12 analyses of unknowns bracketed by two analyses of a standard zircon (GEMOC GJ1, age 609 $\mathrm{Ma}$ ) at the beginning and end of each run. The 'unknowns' include two nearconcordant reference zircons, 91500 (ref. 38) and Mud Tank ${ }^{39}$, which are analysed before the samples and are used as independent control on reproducibility and instrument stability.

The major problem of the $\mathrm{U}-\mathrm{Pb}$ analysis of perovskite is the presence of high contents of common $\mathrm{Pb}$. Instead of applying a common- $\mathrm{Pb}$ correction, we have used a regression technique, treating population of analyses from a single sample as representing mixtures between the common- $\mathrm{Pb}$ and radiogenic- $\mathrm{Pb}$ components. The intercepts of the regression line through the raw data on an inverse-Concordia (Tera-Wasserburg) plot thus provide both an estimate of the ${ }^{207} \mathrm{~Pb} /{ }^{206} \mathrm{~Pb}$ of the common- $\mathrm{Pb}$ component (upper intercept) and the inferred crystallization age (lower intercept).

A total of 40 perovskites from sample 77063 were analysed during two sessions in April and June 2010. After rejection of 12 analyses with the largest analytical errors, the lower intercept of the regression line through the rest of the data $(n=28)$ gave an age of $113 \pm 13 \mathrm{Ma}$, which we consider as the best estimate for the crystallization age of this kimberlite (Supplementary Fig. S1).

Only 12 perovskites were found and analysed from sample 77081. These produce a high MSWD of 2.7 due to a scatter about the regression line. The rejection of four analyses had reduced this scatter (MSWD $=0.63$ ), giving the lower intercept age at $125 \pm 8 \mathrm{Ma}$ and the best estimate for the crystallization age for this sample (Supplementary Fig. S2).

Sixteen out of 17 analyses done for sample 77082 produced a lower intercept age of $121 \pm 13 \mathrm{Ma}$, interpreted as crystallization age for this sample (Supplementary Fig. S3).

\section{References}

1. Girnis, A. V. \& Ryabchikov, I. D. Conditions and mechanisms of generation of kimberlite magmas. Geol. Ore. Deposits 47, 476-487 (2005).

2. Gudfinnsson, G. H. \& Presnall, D. C. Continuous gradations among primary carbonatitic, kimberlitic, melilititic, basaltic, picritic, and komatiitic melts in equilibrium with garnet lherzolite at 3-8GPa. J. Petrol. 46, 1645-1659 (2005).

3. Brey, G. P., Bulatov, V. K., Girnis, A. V. \& Lahaye, Y. Experimental melting of carbonated peridotite at 6-10 GPa. J. Petrol. 49, 797-821 (2008).

4. Mitchell, R. H. Kimberlites, Orangeites, And Related Rocks (Plenum Press, New York, 1995).

5. Jelsma, H., Barnett, W., Richards, S. \& Lister, G. Tectonic setting of kimberlites. Lithos 112, 155-165 (2009)

6. Mitchell, R. H. Kimberlites: Mineralogy, Geochemistry and Petrology (Plenum Press, New York, 1986).

7. Woolley, A. R. et al. Classification of lamprophyres, lamproites, kimberlites, and the kalsilitic, melilitic, and leucitic rocks. Can. Mineral. 34, 175-186 (1996).

8. Tappe, S., Foley, S. F., Jenner, G. A. \& Kjarsgaard, B. A. Integrating ultramafic lamprophyres into the IUGS classification of igneous rocks: rationale and implications. J. Petrol. 46, 1893-1900 (2005).

9. Andronikov, A. V. \& Egorov, L. S. Mesozoic alkaline-ultrabasic magmatism of Jetty Peninsula. Gondwana 8, 547-557 (1993).

10. Andronikov, A. V. \& Foley, S. F. Trace element and Nd-Sr isotopic composition of ultramafic lamprophyres from the East Antarctic Beaver Lake area. Chem. Geol. 175, 291-305 (2001).

11. Andronikov, A. V., Foley, S. F. \& Belyatsky, B. V. Sm-Nd and Rb-Sr isotopic systematics of the East Antarctic Manning Massif alkaline trachybasalts and the development of the mantle beneath the Lambert-Amery rift. Mineral. Petrol. 63, 243-261 (1998).

12. Foley, S. F., Andronikov, A. V. \& Melzer, S. Petrology of ultramafic lamprophyres from the Beaver Lake area of Eastern Antarctica and their relation to the breakup of Gondwanaland. Mineral. Petrol. 74, 361-384 (2002).

13. Sun, S.-S. \& McDonough, W. F. Magmatism in the Ocean Basins. (eds Saunders, A. D. \& Norry, M. J.) Geol. Soc. Spec. Publ. 42, 313-345 (1989).

14. Woodhead, J., Hergt, J., Phillips, D. \& Paton, C. African kimberlites revisited: in situ Sr-isotope analysis of groundmass perovskite. Lithos 112, 311-317 (2009).

15. Belyatski, B. V., Anotonov, A. V., Rodionov, N. V., Laiba, A. A. \& Sergeev, S. A. Age and composition of carbonatite kimberlite dykes in the Prince Charles Mountains, East Antarctica. 9th International Kimberlite Conference Extended Abstracts. 9IKC-A-00272 (Frankfurt, 2008).

16. Egorov, L. S., Yu Mel'nik, A. \& Uykhanov, A. V. The first Antarctic occurrence of a dike kimberlite containing syngenetic calcite carbonatite schlieren. Doklady Rossiyskoy Akademii Nauk 328, 230-233 (1993). 
17. Tappe, S. et al. Craton reactivation on the Labrador Sea margins: ${ }^{40} \mathrm{Ar} /{ }^{39} \mathrm{Ar}$ age and $\mathrm{Sr}-\mathrm{Nd}-\mathrm{Hf}-\mathrm{Pb}$ isotope constraints from alkaline and carbonatite intrusives. Earth Planet. Sci. Lett. 256, 433-454 (2007).

18. Rosenthal, A., Foley, S. F., Pearson, D. G., Nowell, G. M. \& Tappe, S. Petrogenesis of strongly alkaline primitive volcanic rocks at the propagating tip of the western branch of the East African Rift. Earth Planet. Sci. Lett. 284, 236-248 (2009).

19. Powell, C. M., Roots, S. R. \& Veevers, J. J. Pre-breakup continental extension in East Gondwanaland and the early opening of the eastern Indian Ocean. Tectonophys. 155, 261-283 (1988).

20. Phillips, G. \& Laeufer, A. L. Brittle deformation relating to the CarboniferousCretaceous evolution of the Lambert Graben, East Antarctica: a precursor for Cenozoic relief development in an intraplate and glaciated region. Tectonophys. 471, 216-224 (2009).

21. Boger, S. D. \& Wilson, C. J. L. Brittle faulting in the Prince Charles Mountains, East Antarctica: cretaceous transtensional tectonics related to the break-up of Gondwana. Tectonophys. 367, 173-186 (2003).

22. Harrowfield, M., Holdgate, G. R., Wilson, C. J. L. \& McLoughlin, S. Tectonic significance of the Lambert Graben, East Antarctica: reconstructing the Gondwanan rift. Geology 33, 197-200 (2005).

23. Kent, R. Lithospheric uplift in eastern Godwana: evidence for a long-lived mantle plume system? Geology 19, 19-23 (1991).

24. Norman, M. D., Griffin, W. L., Pearson, N. J., Garcia, M. O. \& O’Reilly, S. Y. Quantitative analysis of trace element abundances in glasses and minerals: a comparison of laser ablation inductively coupled plasma mass spectrometry, solution inductively coupled plasma mass spectrometry, proton microprobe and electron microprobe data. J. Anal. Atom. Spectrom. 13, 477-482 (1998).

25. Maas, R., Kamenetsky, M. B., Sobolev, A. V., Kamenetsky, V. S. \& Sobolev, Sr $\mathrm{N}$. V. Nd, and $\mathrm{Pb}$ isotope evidence for a mantle origin of alkali chlorides and carbonates in the Udachnaya kimberlite, Siberia. Geology 33, 549-552 (2005).

26. Vance, D. \& Thirlwall, M. F. An assessment of mass discrimination in MCICPMS using Nd isotopes. Chem. Geol. 185, 227-240 (2002).

27. Kaminsky, F. V. et al. Kimberlitic sources of super-deep diamonds in the Juina area, Mato Grosso State, Brazil. Lithos 114, 16-29 (2010).

28. Waight, T. E., Baker, J. \& Willigers, B. Rb isotope dilution analyses by MCICPMS using $\mathrm{Zr}$ to correct for mass fractionation: towards improved $\mathrm{Rb}-\mathrm{Sr}$ geochronology? Chem. Geol. 186, 99-116 (2002).

29. Ludwig, K. R. ISOPLOT/Ex version 3.0: a geochronological toolkit for MS Excel. Berkeley Geochronol. Center Special Publ. 4, 1-70 (2003).

30. Kaminsky, F. V., Sablukov, S. M., Sablukova, L. I. \& Zakharchenko, O. D. The Fazenda Largo off-craton kimberlites of Piau State, Brazil. J. S. Am. Earth Sci. 28, 288-303 (2009).

31. Kent, R. W., Kelley, S. P. \& Pringle, M. S. Mineralogy and Ar-40/Ar-39 geochronology of orangeites (Group II kimberlites) from the Damodar Valley, eastern India. Mineral. Mag. 62, 313-323 (1998).

32. Lehmann, B. et al. Diamondiferous kimberlites in central India synchronous with Deccan flood basalts. Earth Planet. Sci. Lett. 290, 142-149 (2010).

33. Read, G. et al. Stratigraphic relations, kimberlite emplacement and lithospheric thermal evolution, Quirico basin, Minas Gerais state, Brazil. Lithos 77, 803-818 (2004).

34. Bizimis, M., Salters, V. J. M. \& Dawson, J. B. The brevity of carbonatite sources in the mantle: evidence from Hf isotopes. Contrib. Mineral. Petrol. 145, 281-300 (2003).

35. Münker, C., Weyer, S., Scherer, E. \& Mezger, K. Separation of high field strength elements (Nb, Ta, Zr, Hf) and Lu from rock samples for MC-ICPMS measurements. Geochem. Geophys. Geosys. 2, 1065 (2001).

36. Schmitz, M. D. \& Schoene, B. Derivation of isotope ratios, errors, and error correlations for $\mathrm{U}-\mathrm{Pb}$ geochronology using ${ }^{205} \mathrm{~Pb}^{2}{ }^{235} \mathrm{U}-\left({ }^{233} \mathrm{U}\right)$-spiked isotope dilution thermal ionization mass spectrometric data. Geochem. Geophys. Geosys. 8, Q8006 (2007).

37. Batumike, J. M. et al. LAM-ICPMS U-Pb dating of kimberlitic perovskite: Eocene-Oligocene kimberlites from the Kundelungu Plateau, D.R. Congo. Earth Planet. Sci. Lett. 267, 609-619 (2008).

38. Wiedenbeck, M. et al. Three natural zircon standards for U-Th-Pb, Lu-Th, trace element and REEanalyses. Geostandards Newsletters 19, 1-23 (1995).

39. Black, L. P. \& Gulson, B. L. The age of the Mud Tank carbonatite, Strangways Range, Northern Territory. J. Aust. Geol. Geophys. 3, 227-232 (1978).

40. Veevers, J. J., Tewari, R. C. \& Mishra, H. K. Aspects of Late Triassic to Early Cretaceous disruption of the Gondwana coal bearing fan of east-central
Gondwanaland in Gondwana Nine, Ninth International Gondwana Symposium. (eds Guha, P. K. S., Sengupta, S., Ayyasami, K. \& Ghosh, R. N.) 637-646 (A.A. Balkema Publishers, Rotterdam, 1996).

41. Chalapathi Rao, N. V., Lehmann, B., Mainkar, D. \& Belyatsky, B. Petrogenesis of the end-Cretaceous diamondiferous Behradih orangeite pipe: implication for mantle plume-lithosphere interaction in the Bastar craton, Central India. Contrib. Mineral. Petrol. 161, 721-742 (2011).

42. Tompkins, L. A. \& Gonzaga, G. M. Diamonds in Brazil and a proposed model for the origin and distribution of diamonds in the Coromandel region, Minas Gerais, Brazil. Econ. Geol. 84, 591-602 (1989).

43. Becker, M. \& Le Roex, A. P. Geochemistry of South African on- and off-craton, Group I and Group II kimberlites: petrogenesis and source region evolution. J. Petrol. 47, 673-703 (2006).

44. Gaffney, A. M. et al. Constraints on source-forming processes of West Greenland kimberlites inferred from Hf-Nd isotope systematics. Geochim. Cosmochim. Acta 71, 2820-2836 (2007).

45. Harris, M., le Roex, A. \& Class, C. Geochemistry of the Uintjiesberg kimberlite, South Africa: petrogenesis of an off-craton, group I, kimberlite. Lithos 74, 149-165 (2004).

46. Kopylova, M. G. \& Hayman, P. Petrology and textural classification of the Jericho kimberlite, northern Slave Province, Nunavut, Canada. Can. J. Earth Sci. 45, 701-723 (2008).

47. Kostrovitsky, S. I. Isotope-geochemical systematics of kimberlites and related rocks from the Siberian Platform. Russ. Geol. Geophys. 48, 272-290 (2007).

48. Le Roex, A. P., Bell, D. R. \& Davis, P. Petrogenesis of group I kimberlites from Kimberley, South Africa: evidence from bulk-rock geochemistry. J. Petrol. 44, 2261-2286 (2003).

49. Price, S. E., Russell, J. K. \& Kopylova, M. G. Primitive magma from the Jericho Pipe, NWT, Canada: Constraints on primary kimberlite melt chemistry. J. Petrol. 41, 789-808 (2000).

50. Rao, N. V. C., Gibson, S. A., Pyle, D. M. \& Dickin, A. P. Petrogenesis of Proterozoic lamproites and kimberlites from the Cuddapah Basin and Dharwar Craton, southern India. J. Petrol. 45, 907-948 (2004).

51. Nielsen, T. F. D. \& Jensen, S. M. The Majuagaa calcite-kimberlite dyke, Maniitsoq, southern West Greenland. Geol. Survey Denmark Greenland Rep. 43, 1-59 (2005).

\section{Acknowledgements}

G.T.N. thanks R.F. Flint and ANARE expeditioners for assistance during the summers of 1987-88, 1988-89 and 1989-90. C. Lawson and N. Pearson (Macquarie University) provided XRF analyses and electron microprobe time, respectively. We acknowledge funding from the Australian Research Council (V.S.K. and G.M.Y.), the University of Tasmania (V.S.K.) and a Marie Curie International Incoming Fellowship (302637) to A.R. This is contribution 312 from the ARC Centre of Excellence for Core to Crust Fluid Systems (http://www/ccfs/mq/.edu.au) and 878 in the GEMOC Key Centre (http://www.gemoc.mq.edu.au)

\section{Author contributions}

The manuscript and the ideas therein were mainly developed by G.M.Y., V.S.K., A.R. and G.T.N., with contributions from all other co-authors. G.T.N. collected the samples, performed the EPMA and XRF analyses. M.N. performed the whole rock ICP-MS analyses. R.M. performed the solution mode radiogenic isotope analyses, whereas E.B. contributed the laser-ablation $\mathrm{U}-\mathrm{Pb}$ perovskite ages and in situ $\mathrm{Sr}-\mathrm{Nd}$ isotopic measurements for perovskite. V.S.K. performed s.e.m. analysis.

\section{Additional information}

Supplementary Information accompanies this paper at http://www.nature.com/ naturecommunications

Competing financial interests: The authors declare no competing financial interests

Reprints and permissions information is available online at http://npg.nature.com/ reprintsandpermissions/

How to cite this article: Yaxley, G. M. et al. The discovery of kimberlites in Antarctica extends the vast Gondwanan Cretaceous province. Nat. Commun. 4:2921 doi: $10.1038 /$ ncomms3921 (2013). 